\title{
Protein kinase G type-I phosphorylates c-Src at serine-17 and promotes cell survival, proliferation and attachment in human mesothelioma and non-small cell lung cancer cells
}

\author{
Ronald R Fiscus ${ }^{*}$, Mary G Johlfs
}

From 5th International Conference on cGMP: Generators, Effectors and Therapeutic Implications Halle, Germany. 24-26 June 2011

\section{Background}

Previously, we demonstrated that protein kinase G type-I $\alpha$ (PKG-I $\alpha$ ) plays an important role in promoting cell survival in neural cells (N1E-115 neuroblastoma and NG10815 neuroblastoma-glioma hybrid cells) and significantly contributes to the serine-155 phosphorylation of BAD, an apoptosis-regulating protein [1]. We also found that PKGIa promotes cell survival and proliferation in mouse OP9 bone marrow stromal cells [2] and human ovarian cancer cells [3] [determined by using both pharmacological inhibitors (ODQ, DT-2 and DT-3) and gene knockdown (siRNA) to reduce PKG-I $\alpha / \beta$ activity]. In the case of ovarian cancer cells, which predominantly express the PKG-I $\alpha$ isoform, the pro-growth and pro-survival effects involved a novel interaction between PKG-I $\alpha$ and the oncogenic protein c-Src [3]. For example, intracellular activation of PKG-I $\alpha$, assessed by VASP serine-239 phosphorylation, was dependent on c-Src-catalyzed tyrosine phosphorylation of PKG-Ia (i.e. VASP phosphorylation was blocked by Src inhibitors, SKI-1 or SU6656) and the intracellular activation of c-Src was (somehow) dependent on the kinase activity and expression levels of PKG-Ia (i.e. c-Src activation was decreased by DT-2 or siRNA-induced knockdown of PKG-I $\alpha$ ).

\section{Hypothesis, research plan and methods}

We hypothesize that c-Src activation in cancer cells involves the PKG-I $\alpha$-catalyzed phosphorylation of a

\footnotetext{
* Correspondence: rfiscus@usn.edu

Center for Diabetes \& Obesity Prevention, Treatment, Research \& Education, and the College of Pharmacy, Roseman University of Health Sciences (formerly the University of Southern Nevada), Henderson, Nevada, USA
}

serine or threonine residue of c-Src, likely serine-17 (because amino acid residues around the serine-17 site of c-Src provide a good consensus sequence for PKG-I $\alpha / \beta$ ). The present study determines: 1 ) if PKG-I $\alpha / \beta$ can directly phosphorylate $\mathrm{c}-\mathrm{Src}$ at serine-17 using in vitro conditions, 2) if serine-17-phophorylation of c-Src, in intact cancer cells, is dependent on PKG-I $\alpha / \beta$ expression and kinase activity (using pharmacological inhibitors and shRNA gene knockdown), and 3) if the same inhibition/ knockdown of PKG-I $\alpha / \beta$ alters cell survival, proliferation and attachment. Objectives \# 2 and 3 were tested in a non-small cell lung cancer (NSCLC) cell line, NCI-H23, and two mesothelioma cell lines, MSTO-211H and NCIH2052. The serine-17 phosphorylation of c-Src was determined by Western blot analysis using an antibody (developed in collaboration with Cell Signaling Technologies) that is specific for the phosphorylated-serine-17 site of c-Src. Protein expression of PKG-I $\alpha$ and PKG-I $\beta$ was determined by both conventional Western blot analysis and a new ultrasensitive, highly-quantitative capillary-electrophoresis-based immuno-quantification system, the NanoPro100 system (Cell Biosciences, Inc., Santa Clara, CA, USA). The NanoPro100 system allows clear separation and identification of the different PKG-I isoforms and phosphorylated forms.

\section{Results}

In in vitro incubations using recombinant human c-Src and either PKG-I $\alpha$ or PKG-I $\beta$, both recombinant PKG-I $\alpha$ and PKG-I $\beta$ were able to directly catalyze the phosphorylation of serine-17 in c-Src, resulting in increased autophosphorylation of c-Src at tyrosine-419 (equivalent to tyrosine-416 in mouse c-Src). The NSCLC cells (NCI-H23 
lung cancer cells) were found to express only the PKG-I $\alpha$ isoform, whereas both of the mesothelioma cell lines (MSTO-211H and NCI-H2052) express both PKG-I $\alpha$ and PKG-I $\beta$. In all cell lines, inhibition of PKG-I $\alpha / \beta$ kinase activity using DT-2 or silencing of PKG-I $\alpha / \beta$ expression using shRNA dramatically reduced the intracellular phosphorylation of c-Src at serine-17, whereas addition of the PKG activator 8-bromo-cGMP increased c-Src phosphorylation at serine-17. Both the kinase-activity inhibition and knockdown of PKG-I $\alpha / \beta$ caused significant increases in apoptosis (i.e. decreases in cell survival) and dramatically decreased the cell proliferation, colony formation and cell attachment in both the lung cancer and mesothelioma cells.

\section{Conclusion}

The mesothelioma cells in this study express both PKGI $\alpha$ and PKG-I $\beta$, and the inhibition of their expression or kinase activity results in dramatic suppression of the phosphorylation of c-Src at serine-17 and the endogenous activation of c-Src as well as the cell survival, proliferation and attachment of these cells. Because the kinase inhibitors and shRNA constructs are (at present) not able to discriminate between the two PKG-I isoforms, it is not yet possible to identify which PKG-I isoform is mediating the c-Src phosphorylation and the pro-survival, progrowth and pro-attachment effects of PKG-I in mesothelioma cells. In the NCI-H23 lung cancer cells, which express only the PKG-I $\alpha$ isoform, the PKG-I $\alpha$ was identified as a key protein kinase mediating the enhanced phosphorylation and activation of c-Src and the downstream enhancement of cell survival (contributing to chemoresistance), proliferation and attachment of these lung cancer cells. This builds upon our previous observation that c-Src kinase activity promotes tyrosine-phosphorylation and activation of PKG-I $\alpha$ in ovarian cancer cells. Thus, it appears that the interactions between c-Src and PKG-I in cancer cells may represent a novel "oncogenic re-enforcement”, with each protein kinase phosphorylating and enhancing the kinase activity of the other, ultimately contributing to chemoresistance and tumor growth. This interaction between c-Src and PKG-I may provide a novel target for the development of new anticancer therapeutic agents.

Published: 1 August 2011

\section{References}

1. Johlfs MG, Fiscus RR: Protein kinase $G$ type-la phosphorylates the apoptosis-regulating protein Bad at serine 155 and protects against apoptosis in N1E-115 cells. Neurochem Int 2010, 56:546-553.

2. Wong JC, Fiscus RR: Essential roles of the nitric oxide (NO)/cGMP/protein kinase $G$ type-la (PKG-la) signaling pathway and the atrial natriuretic peptide (ANP)/cGMP/PKG-la autocrine loop in promoting proliferation and cell survival of OP9 bone marrow stromal cells. J Cell Biochem 2011, 112:829-839.

3. Leung EL, Wong JC, Johlfs MG, Tsang BK, Fiscus RR: Protein kinase G type la activity in human ovarian cancer cells significantly contributes to enhanced Src activation and DNA synthesis/cell proliferation. Mol Cancer Res 2010, 8:578-591.

doi:10.1186/1471-2210-11-S1-O31

Cite this article as: Fiscus and Johlfs: Protein kinase G type-I phosphorylates c-Src at serine-17 and promotes cell survival, proliferation and attachment in human mesothelioma and non-small cell lung cancer cells. BMC Pharmacology 2011 11(Suppl 1):O31.

\section{Submit your next manuscript to BioMed Central and take full advantage of:}

- Convenient online submission

- Thorough peer review

- No space constraints or color figure charges

- Immediate publication on acceptance

- Inclusion in PubMed, CAS, Scopus and Google Scholar

- Research which is freely available for redistribution

Submit your manuscript at www.biomedcentral.com/submit
( Biomed Central 